\title{
EFEKTIVITAS LATIHAN BEBAN DENGAN METODE CIRCUIT WEIGHT TRAINING DENGAN SUPER SET TERHADAP PENURUNAN BERAT BADAN DAN PROSENTASE LEMAK
}

\section{Oleh:}

Prabowo Purwanto dan Ahmad Nasrulloh

Pendidkan Kesehatan dan Rekreasi FIK UNY

\section{Abstrak}

Penelitian ini bertujuan untuk: (1) Mengetahui pengaruh metode latihan circuit weight training terhadap penurunan berat badan dan prosentase lemak, (2) Mengetahui pengaruh metode latihan super set terhadap penurunan berat badan dan prosentase lemak, (3) Mengetahui metode manakah yang paling efektif antara metode latihan circuit weight training dengan metode latihan super set terhadap penurunan berat badan dan prosentase lemak pada member Cakra Sport Club.

Penelitian ini adalah pre-eksperimen dengan desain penelitian yang di gunakan yaitu pretest- posttest. Sampel yang digunakan dalam penelitian ini adalah member cakra sport club dengan jumlah 20 member. Pembagian kelompok dalam penelitian ini yaitu kelompok I latihan dengan metode circuit weight training dan kelompok II latihan dengan metode super set. Instrumen yang digunakan yaitu timbangan, alat ukur tinggi badan dan skinfold caliper. Teknik analisis data menggunakan paired t test dan independen $t$ test untuk mengetahui ada pengaruh dan ada perbedaan terhadap sampel.

Hasil Penelitian menunjukan bahwa: (1) Latihan menggunakan metode circuit weight training ada pengaruh yaitu pada berat badan sebelum dan sesudah menggunakan metode circuit weight training sebesar 4,6 \% dan prosentase lemak sebelum dan sesudah menggunakan metode circuit weight training sebesar 19,2 \%. (2) Latihan menggunakan metode super set ada pengaruh pada berat badan sebelum dan sesudah menggunakan metode super set sebesar 2,6\% dan persentase lemak sebelum dan sesudah menggunakan metode super set sebesar 10,5\%. (3) Metode circuit weight training lebih efektif dari pada metode super set untuk menurunkan berat badan dan prosentase lemak. Hal ini dibuktikan dengan nilai prosentase pada penurunan berat badan antara metode circuit weight training dengan metode super set sebesar 4,6\% yang lebih besar dari 2,6\% dan nilai prosentase penurunan prosentase lemak antara metode circuit weight training dengan metode super set sebesar 19,2\% yang lebih besar dari $10,5 \%$.

Kata kunci: Latihan beban, circuit weight training, super set, penurunan berat badan dan presentase lemak.

Latihan beban banyak digunaakan oleh para penggemar kebugaran, bahkan menjadi daya tarik bagi beribu-ribu orang yang pernah menyebut dirinya sebagai orang loyo, orang yang tidak memilki energi yang banyak, dan orang yang tidak bugar. Tetapi dapat menyebabkan perubahan yang dramatis bagi tubuh. Banyak orang melakukan latihan beban mengatakan bahwa dengan memuliki tubuh yang tegap tidak saja terasa bagus, tetapi juga berpengaruh 
terhadap cara anda berhubungan atau berinteraksi dengan orang lain, meningkatkan kekuataan dan daya tahan otot, meningkatnya koordanisai otot dan syaraf.

Dalam melakukan latihan beban di pusat kebugaran sebaiknya memilki tujuan yang jelas dan terarah, artinya mengerti apa yang akan dicapai dalam latihan tersebut. Hal ini dapat kita lihat di pusat kebugaran (fitness centre) yang ada, banyak menawarkan program kebugaran jasmani (physical fitness), penurunan berat badan (fat lose), penambahan berat badan (weight gain), pengencangan (body shaping), pembentukan otot tubuh (hipertrofi), senam aerobic dll. Beberapa orang dalam memilih program latihan Penurunan berat badan beranggapan bahwa menggunakan metode Circuit weight training lebih efektif dari pada menggunakan metode Super set, begitupun sebaliknya. Pemahaman ini juga berpengaruh terhadap member baru, mereka terpengaruh untuk menggunakan metode circuit weight training dengan super set untuk program penurunan berat badan, padahal mereka belum pernah latihan sama sekali.

Banyaknya instruktur dan member yang menerapkan metode kedua tersebut ditempat fitness membuat peneliti ingin mengetahui manakah yang lebih efektif dari kedua metode tersebut agar kedepanya memberikan pemahaman bagi instruktur dan member yang berada difitness centre. Maka dari itu penulis berharap dapat mengetahui pengaruh dari metode kedua tersebut dan kedepanya dapat memberikan program yang sesuai untuk member baru.

Mengapa menggunakan metode circuit weight training, metode ini merupakan suatu bentuk latihan aerobic yang terdiri dari pos-pos latihan,yaitu antara 8 sampai 16 pos latihan. Latihan dilakukan dengan cara berpindah-pindah dari pos satu ke pos dua begitu hingga pos terakhir, karena sebagian orang beranggapan bahwa dengan pos yang banyak dengan irama yang cepat dan waktu istrahat yang pendek membuat pembakaran lemak semakin cepat sedangkan mengapa menggunakan metode super set, karena dengan menggunakan metode ini yaitu agonis dan antagonis dapat membakar lemak dan mengoptimal kan bagian otot yang dituju karena metode ini menggunakan otot bagian depan kemudian menggunakan otot sebaliknya tergantung otot yang dituju dan otot pasangan keterbalikanya. Dengan harapan metode kedua tersebut dapat membantu tercapainya tujuan dari member agar mendapatkan tubuh yang ideal untuk dapat menambah kepercayaan diri mereka selain untuk mendapatkan tubuh yang sehat dan juga tentunya badan yang bugar.

Padahal dalam setiap individu akan berbeda dengan individu lainnya, maka dari itu belum tentu semua orang cocok pada program penurunan berat badan menggunakan circuit weight training, bisa saja seorang lebih cocok menggunakan super set dan bisa juga sebaliknya. Berdasarkan permasalahan yang ada, penelitian ini peneliti ingin mengetahui apa 
pengarug kedua metode tersebut dan yang manakah yang lebih efektif dalam penurunan berat badan dan prosentase lemak yaitu menggunakan metode circuit weight training atau dengan menggunakan metode super set.

\section{KAJIAN PUSTAKA}

\section{Metode Latihan Beban}

Latihan beban dapat dilakukan dengan beberapa sistem atau metode. Metode latihan beban tersebut antara lain:

\section{A. Super Set}

Menurut Suharjana (2013: 33), Super set adalah suatu bentuk latihan dengan cara melatih otot yang berlawanan yaitu agonis dan antagonis secara berurutan. Contohnya latihan dada dilanjutkan dengan latihan punggung, latihan paha depan dilanjutkan dengan latihan paha belakang, yang dilakukan secara berurutan. Super set adalah suatu bentuk latihan dengan cara melatih otot yang berlawanan yaitu agonis dan antagonis secara berurutan. Contohnya latihan dada dilanjutkan dengan latihan punggung, latihan paha depan dilanjutkan dengan latihan paha belakang, yang dilakukan secara berurutan (Djoko Pekik, 2004: 41).

B. Set system

Set sistem merupakan suatu model latihan dengan memberikan pembebanan pada sekelompok otot, beberapa set secara berurutan yang diselingi dengan istirahat (Djoko Pekik I, 2004: 39). Dapat dikatakan system ini yaitu beberapa latihan yang memberikan pembebanan dengan berurutan dan diselingi recovery pada setiap atau antar set.

\section{Circuit Training}

Menurut Suharjana (2013: 49), circuit training merupakan suatu bentuk latihan aerobic yang terdiri dari pos-pos latihan,yaitu antara 8 sampai 16 pos latihan. Latihan dilakukan dengan cara berpindah-pindah dari pos satu ke pos dua begitu hingga pos terakhir. Menurut Sukadiyanto (2011: 112) metode sirkuit biasanya terdiri dari beberapa item atau macam latihan yang harus dilakukan dalam waktu tertentu, setelah selesai satu item latihan segera pindan pada item yang lain tanpa ada waktu recovery atau interval begitu seterusnya sampai item latihan selesai dilakukan maka dikatakan menyelesaikan satu sirkuit. Latihan sirkuit adalah latihan dengan banyak item atau macam dan berbagai pos yang dilakukan dengan berpindah-pindah antar pos atau item hingga rangkaian item latihan selesai semua baru dikatakan satu sirkuit. Latihan sirkuit, salah satu sistem latihan beban yang umum digunakan untuk membakar lemak adalah dengan latihan sirkuit atau 
lebih dikenal dengan circuit weight training. Latihan ini pada dasarnya adalah memadukan prinsip latihan beban dengan prinsip latihan sirkuit atau kontinyu, pada awalnya latihan ini dirancang untuk meningkatkan daya tahan dan kekuatan otot sambil melatih system aerobik, selanjutnya berkembang untuk memperbaiki komposisi tubuh

D. Compound Set

Menurut Suharjana (2013: 89) system ini diterapkan untuk melatih otot berurutan dengan bentuk latihan berbeda. Misalnya melatih otot biseps pada set 1 menggunakan beban mesin, kemudian set 2 menggunakan dumbbell. Compound set merupakan latihan yang diterapkan untuk melatih sekelompok otot secara berurutan dengan bentuk latihan yang berbeda. Misalnya melatih otot biceps pada set 1 menggunakan mesin, kemudian set 2 menggunakan dumbell (Djoko Pekik I, 2006: 42). Dapat dikatakan bahwa latihan menggunakan system ini memadukan latihan antara latihan menggunakan beban mesin dengan menggunakan beban dumbbell secara berurutan.

\section{Berat Badan}

Berat badan merupakan ukuran antropometri yang terpenting pada tubuh, berat badan merupakan hasil peningkatan atau penurunan semua jaringan yang ada pada tubuh. Menurut Henhy (2008: 79) berat badan ideal merupakan dambaan dari setiap manusia baik tua maupun muda, karena baik dari segi penampilan fisik maupun dari segi kesehatan. Terutama kaum muda lebih banyak yang mendambakan karena dengan berat yang ideal penampilan fisik akan menjadi lebih menarik. Berbagai cara dilakukan agar dapat mencapai berat badan yang ideal baik dari mengatur pola makan, diet ketat, berolahraga yang teratur sampai dengan meminum obat-obatan. Latihan kebugaran untuk menurunkan berat badan harus memperhatikan prinsip serta tahap latihan. Prinsip latihan penurunan berat badan adalah specifity (kekhususan) yaitu menggunakan latihan aerobic karena lemak dapat terbakar setelah latihan minimal selama 20 menit, sedangkan tahap latihan tetap harus mengacu pada pemanasan, inti, dan pendinginan.

Latihan beban juga dapat digunakan sebagai model latihan penurunan berat badan asal memenuhi persyaratan, antara lain: menggunakan metode sirkuit, detak jantung latihan dapat dipertahankan antara 65-75\% dari denyut jantung maksimal,dan latihan dikerjakan lebih dari 20 menit (Suharjana, 2013:129-130). Latihan beban juga dapat digunakan sebagai model latihan penurunan berat badan asal memenuhi persyaratan, antara lain : menggunakan metode sirkuit, detak jantung latihan dapat dipertahankan antara 65-75\% dari denyut jantung maksimal,dan latihan dikerjakan lebih dari 20 menit. Apabila persyaratan tersebut tidak dapat 
terpenuhi, maka weight training tidak efektif untuk menurunkan berat badan sebab weight training dirancang untuk melatih kebugaran otot (Djoko Pekik, 2004: 84). Salah satu contoh program penurunan berat badan dapat dilihat dari tabel 1 dibawah ini.

\section{Tabel 1. Penurunan Berat Badan}

\begin{tabular}{|l|l|l|}
\hline Bentuk Latihan : & Frekuensi : 3-4 kali/minggu & Latihan seluruh \\
Latihan Beban & Intensitas : <70 \% RM/1 & otot \\
(Weight Training) & RM & Pos :12-16 \\
& Repetisi : 15-20 kali rep & Irama : lambat - sedang \\
& Set : 2-3 set & Metode : Circuit \\
& Recovery : 20 - 30 detik & training \\
& antar & Intensitas : Sedang \\
& sesi, > 90 detik antar sirkuit & Durasi : lama \\
\hline
\end{tabular}

(Suharjana ,2013: 130).

\section{Lemak}

Brian J. Sharkey (2003: 238), lemak merupakan komponen yang penting dari dinding sel, insulasi vital dalam system saraf, pendahulu dari komponen penting seperti hormon, dan penyerap goncangan pada organ dalam. Dan lemak dapat menjadi bahan bakar yang paling efisien untuk melakukan aktifitas fisik, khususnya pada otot yang telah menjalani latihan daya tahan. Menurut Noerhadi (2006: 51) lemak adalah zat kaya energi dan merupakan cadangan energi yang terbesar dalam tubuh. Lemak mengandung energi lebih tinggi dibandingkan karbohidrat dan protein, ada 2 jenis asam lemak yaitu lemak jenuh dan lemak tidak jenuh.

Lemak jenuh adalah lemak yang terdapat pada minyak hewani, mengandung kolesterol tinggi sehingga mengkonsumsi lemak jenuh secara berlebihan tidak baik bagi kesehatan. Kemudian lemak tak jenuh adalah lemak yang banyak terdapat pada minyak nabati dan mengandung kolesterol rendah sehingga mengkonsumsi lemak tak jenuh baik bagi kesehatan. Menurut Brian J. Sharkey (2003: 281-282) metode standar untuk menentukan persentase lemak tubuh adalah menimbang berat badan diair. Subyek yang telanjang ditimbang baik di darat dan ketika di bawah permukaan air. Metode lain yang dapat digunakan untuk menghitung persentase lemak tubuh menggunakan skinfold caliper.

\section{Program Latihan}

Dari tujuan dan sasaran yang ingin diteliti oleh peneliti yaitu untuk mengetahui efektifitas dan pengaruh metode circuit weight training dengan metode super set terhadap penurunan berat badan dan presentase lemak maka program yang dipilih yaitu penurunan berat badan dengan contoh tabel program yaitu: 
Tabel 2. Program latihan Penurunan Berat Badan

\begin{tabular}{|l|l|l|}
\hline Bentuk Latihan: & Frekuensi: $3-4$ kali/minggu & Latihan seluruh \\
(Weight Training) & Intensitas: <70\% RM/1RM & otot \\
& Repetisi: $15-20$ kali rep & Pos :12-16 \\
& Set: $2-3$ set & Irama: lambat - \\
Recovery : 20 - 30 detik antar sesi, > & sedang \\
90 detik antar sirkuit & Metode: Circuit \\
& & training \\
& & Intensitas: Sedang \\
& Durasi: lama \\
\hline
\end{tabular}

(Suharjana ,2013: 130).

Melihat dari bentuk latihan di atas peneliti mengambil Program latihan yang telah ditentukan melihat dan mempertimbangkan keadaan dan yang ingin diteliti oleh peneliti yaitu efektivitas dan pengaruh antara metode circuit weight training dengan metode super set pada member Cakra Sport Club maka dibuat lah program bentuk latihan penurunan berat badan sebagai berikut:

Tabel 3. Bentuk latihan metode circuit weight training untuk penurunan berat badan

\begin{tabular}{|l|l|l|}
\hline Bentuk Latihan: & Frekuensi: $3 \mathrm{kali} / \mathrm{minggu}$ & Latihan seluruh \\
Latihan Beban & Intensitas: $50 \% 1 \mathrm{RM}$ & otot \\
(Weight Training) & Repetisi: $15 \mathrm{kali}$ rep & Pos :12 \\
& Set: 3 set & Irama: sedang \\
& Recovery: 30 detik antar & Metode: Circuit \\
& sesi, 120 detik antar sirkuit & training \\
& & Intensitas e: Sedang \\
& & Durasi : lama \\
\hline
\end{tabular}

Tabel 4. Bentuk latihan metode super set untuk penurunan berat badan

\begin{tabular}{|l|l|l|}
\hline Bentuk Latihan: & Frekuensi: 3 kali/minggu & Latihan seluruh \\
Latihan Beban & Intensitas: $50 \% 1 \mathrm{RM}$ & otot \\
(Weight Training) & Repetisi: $15 \mathrm{kali}$ rep & Pos :12 \\
& Set: 3 set & Irama: sedang \\
& Recovery: 30 detik antar & Metode: Super set \\
& sesi, 120 detik antar sirkuit & Intensitas: Sedang \\
& & Durasi: lama \\
\hline
\end{tabular}


Urutan Perlakuan Circuit Weight Training

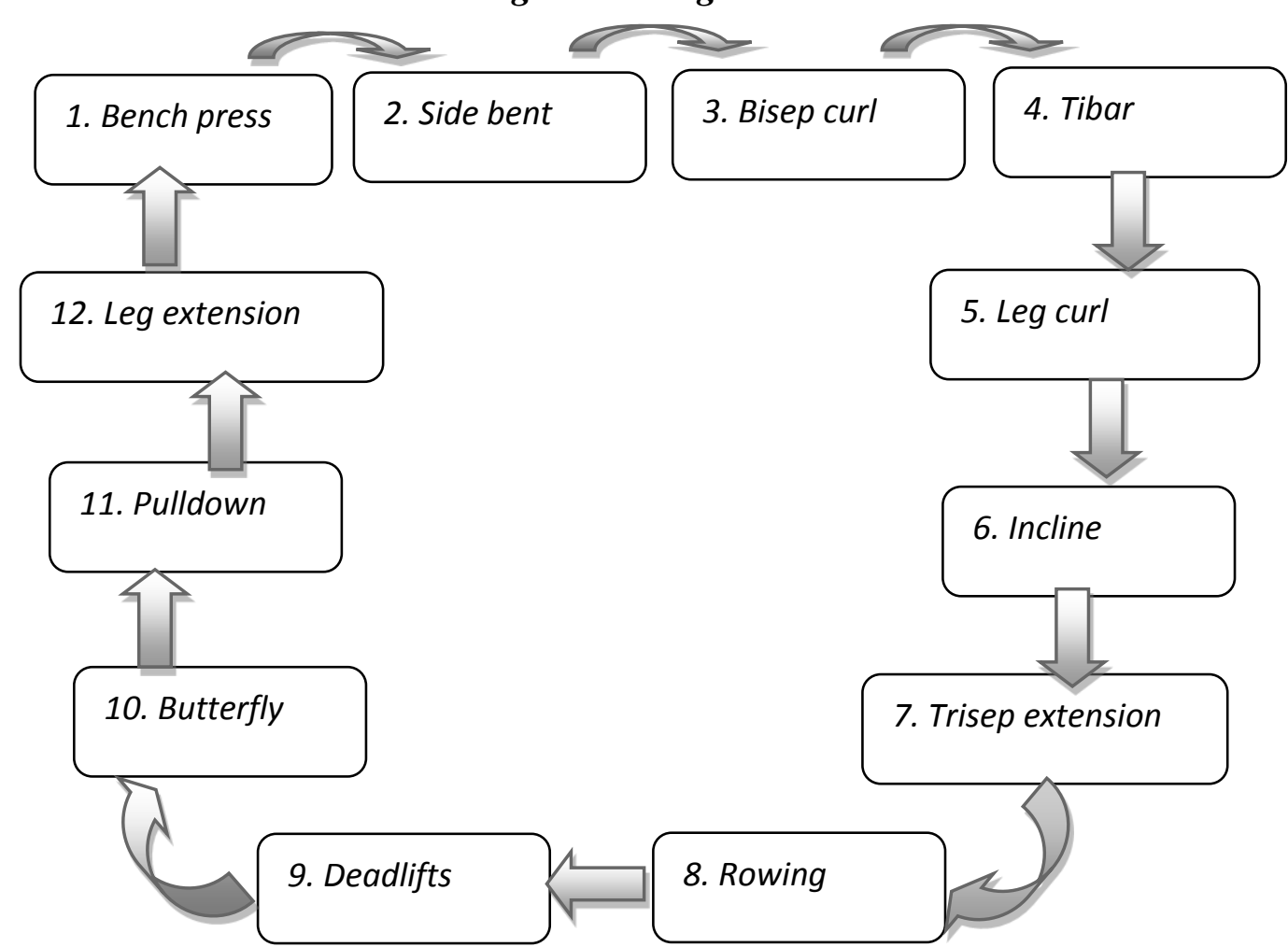

Gambar 1. Urutan Perlakuan Circuit Weight Training (Frederic Delavier, 2001) Urutan Perlakuan Super set

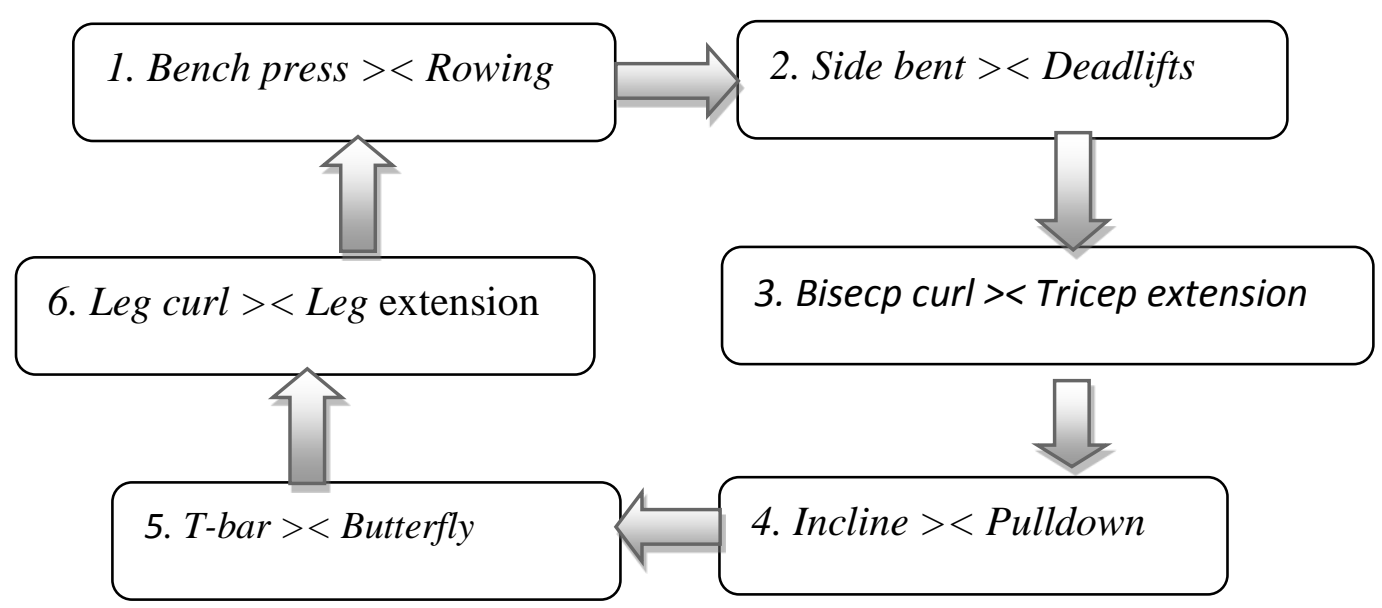

\section{METODE PENELITIAN}

Gambar 2. Urutan Perlakuan Super set (Frederic Delavier, 2001).

Penelitian ini merupakan penelitian pre-experimental design, penelitian ini menggunakan desain pretest and posttest group, dalam penelitian ini adanya dua treatment maka menggunakan desain penelitian "two group pre test post test." Dapat dikatakan bahwa jenis penelitian ini membandingkan antara pretest dan posttest, kelompok-kelompok dalam penelitian di beri perlakuan. Kelompok I diberi perlakuan (treatment) latihan menggunakan metode circuit weight training dan kelompok II diberi perlakuan (treatment) dengan metode Efektifitas Latihan Beban Dengan Metode Circuit Weight Training dengan Super Set Terhadap Penurunan Berat Badan dan Prosentase Lemak (Oleh: Prabowo Purwanto dan Ahmad Nasrulloh) 
super set, terhadap penurunan berat badan dan presentase lemak, sebelum dan sesudah perlakuan diberikan, Pembagian kelompok dilakukan dengan cara merangking hasil pretest, kemudian dipasangkan dengan pola A-B-B-A (ordinal pairing) dalam dua kelompok anggota masing-masing 10 member.

Populasi yang digunakan dalam penelitian ini adalah member fitness pria/laki-laki yang berada di Cakra sport club yang berjumlah 70 orang. Sampel dari penelitian ini adalah member fitness laki-laki pada Cakra sport club. Dalam penelitian ini dari populasi 70 orang dipilih 20 orang member laki-laki dengan cara pengambilan sampel bertujuan (purposive sampling).

\section{HASIL PENELITIAN}

Penelitian ini bertujuan untuk mengetahui yang manakah yang lebih efektif dalam penurunan berat badan yaitu menggunakan metode circuit weight training atau dengan menggunakan metode super set. Sampel dalam penelitian ini terdiri dari dua kelompok yaitu kelompok dengan metode super set dan kelompok dengan metode circuit weight training. Hasil analisis deskriptif variabel penelitian sebagai berikut ini:

A. Nilai Pretest dan Posttest Berat Badan Pada Kelompok dengan Metode Super set

Hasil pretest berat badan pada kelompok dengan metode super set dapat dilihat pada tabel berikut:

Tabel 6. Hasil Pretest dan Posttest Berat Badan dengan Metode Super set

\begin{tabular}{|c|c|c|c|}
\hline No Subjek & Pretest BB & Posttest BB & $\begin{array}{c}\text { Prosentase } \\
\text { Penurunan }\end{array}$ \\
\hline 1 & 79 & 77 & $2,5 \%$ \\
\hline 2 & 75 & 74 & $1,3 \%$ \\
\hline 3 & 80 & 79 & $1,3 \%$ \\
\hline 4 & 70 & 68 & $2,9 \%$ \\
\hline 5 & 78 & 75 & $3,8 \%$ \\
\hline 6 & 98 & 96 & $2,0 \%$ \\
\hline 7 & 85 & 83 & $2,4 \%$ \\
\hline 8 & 75 & 71 & $5,3 \%$ \\
\hline 9 & 79 & 77 & $2,5 \%$ \\
\hline 10 & 80 & 78 & $2,5 \%$ \\
\hline Mean & 79,9 & 77,8 & $2,6 \%$ \\
\hline Standar Deviasi & 7,49 & 7,64 & \\
\hline Minimum & 70 & 68 & \\
\hline Maksimum & 98 & 96 & \\
\hline
\end{tabular}


B. Nilai Pretest dan Posttest Berat Badan Kelompok dengan Metode Circuit Weight Training

Berat badan member fitnes sebelum dilakukan latihan dengan menggunakan metode circuit weight training disajikan pada tabel berikut:

Tabel 7. Hasil Pretest dan Posttest Berat Badan dengan Metode Circuit Weight Training

\begin{tabular}{|c|c|c|c|}
\hline No Subjek & Pretest BB & Posttest BB & $\begin{array}{c}\text { Prosentase } \\
\text { Penurunan }\end{array}$ \\
\hline 1 & 86 & 81 & $5,8 \%$ \\
\hline 2 & 80 & 77 & $3,8 \%$ \\
\hline 3 & 85 & 80 & $5,9 \%$ \\
\hline 4 & 83 & 79 & $4,8 \%$ \\
\hline 5 & 83 & 79 & $4,8 \%$ \\
\hline 6 & 80 & 75 & $6,3 \%$ \\
\hline 7 & 86 & 84 & $2,3 \%$ \\
\hline 8 & 65 & 62 & $4,6 \%$ \\
\hline 9 & 92 & 89 & $3,3 \%$ \\
\hline 10 & 85 & 81 & $4,7 \%$ \\
\hline Mean & 82,5 & 78,7 & $4,6 \%$ \\
\hline Standar Deviasi & 7,04 & 7,01 & \\
\hline Minimum & 65 & 62 & \\
\hline Maksimum & 92 & 89 & \\
\hline
\end{tabular}

C. Nilai Pretest dan Posttest Prosentase Lemak Kelompok dengan Metode Super set

Hasil pretest prosentase lemak pada kelompok dengan metode Super set disajikan pada tabel berikut:

Tabel 8. Hasil Pretest dan Posttest Prosentase Lemak dengan Metode Super set

\begin{tabular}{|c|c|c|c|}
\hline No Subjek & Pretest Lemak & Posttest Lemak & $\begin{array}{c}\text { Prosentase } \\
\text { Penurunan }\end{array}$ \\
\hline 1 & 88 & 71 & $19,3 \%$ \\
\hline 2 & 85 & 80 & $5,9 \%$ \\
\hline 3 & 85 & 79 & $7,1 \%$ \\
\hline 4 & 76 & 71 & $6,6 \%$ \\
\hline 5 & 75 & 72 & $4,0 \%$ \\
\hline 6 & 72 & 61 & $15,3 \%$ \\
\hline 7 & 72 & 70 & $2,8 \%$ \\
\hline 8 & 68 & 55 & $19,1 \%$ \\
\hline
\end{tabular}

Efektifitas Latihan Beban Dengan Metode Circuit Weight Training dengan Super Set Terhadap

(Oleh: Prabowo Purwanto dan Ahmad Nasrulloh) 


\begin{tabular}{|c|c|c|c|}
\hline No Subjek & Pretest Lemak & Posttest Lemak & $\begin{array}{c}\text { Prosentase } \\
\text { Penurunan }\end{array}$ \\
\hline 9 & 80 & 64 & $20,0 \%$ \\
\hline 10 & 60 & 58 & $3,3 \%$ \\
\hline Mean & 76,1 & 68,1 & $10,5 \%$ \\
\hline Standar Deviasi & 8,66 & 8,41 & \\
\hline Minimum & 60 & 55 & \\
\hline Maksimum & 88 & 80 & \\
\hline
\end{tabular}

D. Nilai Pretest dan Posttest Prosentase Lemak Kelompok dengan Metode Circuit Weight Training

Prosentase lemak member fitnes sebelum dilakukan latihan dengan menggunakan metode circuit weight training disajikan pada tabel berikut:

Tabel 9. Pretest dan Posttest Prosentase Lemak Kelompok dengan Metode Circuit Weight Training

\begin{tabular}{|c|c|c|c|}
\hline No Subjek & $\begin{array}{c}\text { Pretest } \\
\text { Lemak }\end{array}$ & $\begin{array}{c}\text { Posttest } \\
\text { Lemak }\end{array}$ & $\begin{array}{c}\text { Prosentase } \\
\text { Penurunan }\end{array}$ \\
\hline 1 & 87 & 65 & $25,3 \%$ \\
\hline 2 & 86 & 68 & $20,9 \%$ \\
\hline 3 & 84 & 62 & $26,2 \%$ \\
\hline 4 & 84 & 65 & $22,6 \%$ \\
\hline 5 & 74 & 60 & $18,9 \%$ \\
\hline 6 & 73 & 60 & $17,8 \%$ \\
\hline 7 & 72 & 60 & $16,7 \%$ \\
\hline 8 & 69 & 58 & $15,9 \%$ \\
\hline 9 & 65 & 57 & $12,3 \%$ \\
\hline 10 & 62 & 56 & $9,7 \%$ \\
\hline Mean & 75,6 & 61,1 & $19,2 \%$ \\
\hline Standar Deviasi & 9,08 & 3,87 & \\
\hline Minimum & 62 & 56 & \\
\hline Maksimum & 87 & 68 & \\
\hline & & \multicolumn{3}{|}{} \\
\hline
\end{tabular}

\section{PEMBAHASAN}

Latihan sirkuit, salah satu sistem latihan beban yang umum digunakan untuk membakar lemak adalah dengan latihan sirkuit atau lebih dikenal dengan circuit weight training. Latihan ini pada dasarnya adalah memadukan prinsip latihan beban dengan prinsip latihan sirkuit atau kontinyu, pada awalnya latihan ini dirancang untuk meningkatkan daya tahan dan kekuatan otot sambil melatih system aerobik, selanjutnya berkembang untuk memperbaiki komposisi 
tubuh. Menurut Suharjana (2013: 49), circuit training merupakan suatu bentuk latihan aerobic yang terdiri dari pos-pos latihan, yaitu antara 8 sampai 16 pos latihan. Latihan dilakukan dengan cara berpindah-pindah dari pos satu ke pos dua begitu hingga pos terakhir.

Berdasarkan hasil penelitian dapat diketahui bahwa hipotesis kedua dalam penelitian ini yang menyatakan adanya pengaruh super set terhadap penurunkan berat badan dan presentase lemak diterima oleh hasil penelitian empiris. Super set adalah latihan beban dengan metode agonis dan antagonis dengan model latihan berlawanan dan berurutan yaitu otot perut dilanjutkan otot punggung kemudian otot paha depan dilanjutkan otot paha belakang begitu seterusnya. Menurut Djoko Pekik (2004: 41) super set adalah suatu bentuk latihan dengan cara melatih otot yang berlawanan yaitu agonis dan antagonis secara berurutan. Contohnya latihan dada dilanjutkan dengan latihan punggung, latihan paha depan dilanjutkan dengan latihan paha belakang, yang dilakukan secara berurutan. Dengan menggunakan metode ini yaitu agonis dan antagonis dapat membakar lemak dan mengoptimalkan bagian otot yang dituju karena metode ini menggunakan otot bagian depan kemudian menggunakan otot sebaliknya tergantung otot yang dituju dan otot pasangan keterbalikanya.

Hasil penelitian ini menunjukkan bahwa hipotesis ketiga yang menyatakan bahwa metode circuit weight training lebih efektif dari pada metode super set untuk menurunkan berat badan dan presentase lemak. Hasil tersebut juga terlihat pada rata-rata berat badan dan prosentase lemak setelah latihan dengan menggunakan metode circuit weight training menjadi lebih rendah dari pada setelah latihan dengan menggunakan metode super set. Latihan dengan menggunakan super set maupun dengan menggunakan Circuit Weight Training sama-sama merupakan latihan beban. Akan tetapi hasil penelitian menunjukkan bahwa Circuit Weight Training lebih efektif menurunkan berat badan dari pada super set. Hal ini karena dalam Circuit Weight Training terdapat beberapa pos. Latihan dilakukan dengan cara berpindah-pindah dari pos satu ke pos lainnya dengan waktu istirahat yang pendek sehingga membuat pembakaran lemak semakin cepat jika dibandingkan latihan dengan menggunakan super set. Hal ini sesuai dengan pendapat lyne Bryck (2001) yang menyatakan bahwa didalam tubuh kita senantiasa berlangsung proses biokimia untuk memperoleh energy bagi tiap gerak kerja.

Latihan yang dilakukan pada intensitas rendah sampai sedang dalam waktu 30 menit atau lebih akan membakar lemak. Aerobik yang dilkaukan dalam intensitas yang tinggi dalam waktu yang singkat atau kurang daari 30 menit akan membakar gula. Selain itu, Cooper (2001) juga mengatakan bahwa beberapa peneliti telah membuktikan bahwa dengan 
mencapai tingkat kebugaran yang tiinggi dengan aktivitas olahraga aerobic dapat memberikan manfaat salah satunya adalah perbaikan profil, lipit darah.

\section{KESIMPULAN}

Berdasarkan hasil penelitian dan pembahasan pada bab sebelumnya dapat disimpulkan bahwa: Ada pengaruh circuit weight training terhadap penurunkan berat badan dan presentase lemak. Ada pengaruh super set terhadap penurunkan berat badan dan presentase lemak. Metode circuit weight training lebih efektif dari pada metode super set untuk menurunkan berat badan dan presentase lemak. Penurunan berat badan, prosentase lemak tubuh dan kadar koleterol disebabkan oleh melemahnya aktifitas fisik para sample yang semula melakukan olahraga hanya seminggu sekali dalam intensitas yang rendah dimana sumber energy yang dibutuhkan dari pembakaran cadangan lemak tubuhnya. Dengan meningkatnya aktivitas tersebut, menyebabkan terbakarnya cadangan lemak tubuh untuk memenuhi kebutuhan kalori tubuh pada saat latihan. Latihan olahraga mempunyai pengaruh yang jelas pada penurunan kadar lemak dan kolesterol dalam darah.

\section{DAFTAR PUSTAKA}

Ahmad Nasrulloh. (2016). Pengaruh Metode Latihan Super Set dan Compound Set dengan Istirahat Antar Set 30 dan 120 Detik terhadap Kebugaran Komponen Kesehatan. Surabaya: Disertasi. UNESA

Brian J. Sharkey. (2003). Kebugaran \& Kesehatan. Jakarta: PT Raja Grafindo Persada.

Danardono. (2006). Diktat Perencanaan Program Latihan.Yogyakarta: FIK UNY.

Djoko Pekik. (2004). Bugar dan Sehat dengan Berolahraga. Yogyakarta: C.V Andi Offset.

Djoko Pekik. (2006). Pedoman Praktis Berolahraga untuk Kebugaran dan Kesehatan. Yogyakarta: C.V Andi Offset.

Dwi Hatmisari Ambarukmi, dkk. (2007). Pelatihan Pelatih Fisik Level 1. Jakarta: KEMENPORA.

Faidillah K.S.Pd. (2006). Dasar-dasar Latihan Kebugaran. Yogyakarta : FIK UNY.

Frederic Delavier. (2001). Strength Training Anatomy.Human Kinetics.

Henhy. (2008). Sistem Pengukuran Berat dan Tinggi Badan Menggunakan Mikrokontroler AT89S51. Jurnal Jurusan Teknik Elektro Universitas Tarumanegara.

Sadoso Sumosardjuno. (1994). Pengetahuan Praktis Kesehatan dalam olaharaga. Jakarta: PT. Gramedia. 
Sukadiyanto. (2011). Pengantar Teori dan Metodologi Melatih Fisik.Bandung: Lubuk Agung.

Suharjana. (2013). Kebugaran Jasmani. Yogyakarta: Jogja Global Media.

Sulistiyono. (2007). Pengaruh Latihan Beban Standing Triceps Extension dan Panjang Lengan Terhadap Keterampilan Lemparan Kedalam pada Permainan Sepakbola Siswa Sekolah Sepakbola Biantara Kelompok Umur 17 Tahun Kota Semarang.Jurnal UNNES.

Thomaas. Beachle. Baney R. dan Earle.(2007). Bugar dengan Latihan Beban. Jakarta: PT Raja Grafindo Persada. 